\title{
Iron Deficiency Anemia in School Age Children in District Karak Khyber Pakhtunkhwa Province, Pakistan
}

\author{
Irfan Ullah1, Muhammad Zahid1 ${ }^{*}$, Aftab Alam Sthanadar, ${ }^{1,2}$ Iram Alam Sthanadar1, \\ Pir Asmat Ali', Mudassirshah1,3, Muhammad Ismail Khan', Muhammad Kaleem1, \\ Muhammad Aslam', Khayyam', Atiq-Ur-Rehman', Wasif Ullah' \\ ${ }^{1}$ Department of Zoology, Islamia College University, Peshawar, Pakistan \\ ${ }^{2}$ Department of Zoology and Animal Sciences, Post Graduate College Dargai, Malakand, Pakistan \\ ${ }^{3}$ Government Degree College Dara Adam Kheil, FR Kohat, Pakistan \\ Email: ${ }^{*}$ mzahidsafi75@yahoo.com
}

Received 19 April 2014; revised 23 May 2014; accepted 30 May 2014

Copyright (C) 2014 by authors and Scientific Research Publishing Inc. This work is licensed under the Creative Commons Attribution International License (CC BY). http://creativecommons.org/licenses/by/4.0/

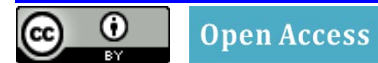

\section{Abstract}

The present study aimed to estimate the prevalence of iron deficiency anemia (IDA) in schoolgoing children. Both Iron deficiency and iron deficiency anemia have considerable adverse effect on human health. Among the different negative health concerns, including stunt development, less developed immunity, lower IQ level, no proper physical work capacity, more fatigue, maternal mortality rates, young ones born with low birth weight, birth complications and infant mortality rates are some of the remarkable health concerns posed by iron deficiency level. Our study sample was consisting of 420 school age children of both genders. The blood samples were collected in EDTA (Ethylenediaminetetraacetic acid) tubes from different school and health maternity centres by trained and veteran persons. Questionnaires were utilised for the data collection, at the time of blood samples collection. Hemoglobin (Hb), hematocrite (Hct), Mean Corpuscular Volume (MCV), Mean Corpuscular hemoglobin concentration (MCHC), white blood cell and red blood cell (RBC) were determine by automatic hematological analyzer model Symex Ks-21 having two reagents, cell pack and Stromatolyser-wwt $500 \mathrm{ml}$. The total percentage of anemia recorded in school age children was $34.0 \%$. In tehsil Banda Daud Shah, the incidence of anemia was high up to $43.6 \%$ while in tehsil Takhti Nasrati and Karak was $32.1 \%$ and $26.4 \%$ respectively. The percentage was higher in girls $(38.9 \%)$ than in boys $(31.0 \%)$. The anemia percentage was recorded high $(55.8 \%)$ in lower socioeconomic family children, than middle class $(32.2 \%)$ and upper class $(17 \%)$. The percentage of anemic children was also high (40\%) in age group of $10-12$ years. Pale skin was the most common symptom of anemia.

\footnotetext{
${ }^{*}$ Corresponding author.
} 


\section{Keywords}

\section{Iron Deficiency Anemia (IDA), Red Blood Cells (RBC), Hemoglobin (Hb), Hematocrit (Hct), Ethylenediamine Tetraacetic Acid (EDTA)}

\section{Introduction}

Anemia is a blood disorder in which the hemoglobin $(\mathrm{Hb})$ concentration is less than the normal Hb concentration for age, sex, physiological condition and altitude. Iron deficiency is the most common cause of anemia [1]. There are different types of anemia including Hemorrhagic anemia due to excessive loss of blood, Hemolytic anemia due to red blood cell destruction and hematopoietic anemia due to less production of RBC. There are many causes of anemia but the most common cause is iron deficiency [2]. Iron deficiency anemia is one of the most common and prevalent, nutritional health problems in infants and young children across the developing world. Approximately 1200 million people are anemic across the globe [3]. According to WHO report, half of all anemia is due to iron deficiency. It is estimated that $43 \%$ of the young children are iron deficient worldwide and the greatest are between age of 1 - 2 years children. In Pakistan 65\% children had IDA at the age 07 - 60 years and other studies estimate different prevalent rates i.e. 70\%, 78\% [4] [5].

It is estimated that approximately 750 million children are affected by IDA [6]. This is most common in children and women in developing countries. It is believed that 700,000 children aged 1 - 2 years are iron deficient (ID) and 240,000 have iron deficiency anemia (IDA) [7]. There are many causes of anemia but the common causes are the deficiency of essential nutrients as Iron, Vitamin B12 and Follic acid. Other factors include blood loss, repeated pregnancy in women, worm infection, hemolysis, suppression of red corpuscles synthesis by bone marrow and gastrointestinal blood loss [8] [9]. The iron deficiency causes microcytic anemia but folic acid, vitamin $\mathrm{B}_{12}$, hyperthyroidism and liver disease cause macrocytic anemia [10]. Some other diseases like diarrhea, filariasis, and parasitic infection that cause blood loss also result in anemia [11]. The cut-off value for hemoglobin level is varying by age, physiological status and race. The Recommended cut-off value for anemia in children aged from 06 - 59 months is $110 \mathrm{~g} / \mathrm{L}, 5$ - 11 years $115 \mathrm{~g} / \mathrm{L}, 12$ - 14 years 120 g/L, adult males 130 $\mathrm{g} / \mathrm{L}[12]$.

The cut-off point for children $<5$ years of age is $11 \mathrm{~g} / \mathrm{dl} ; 7-10.9 \mathrm{~g} / \mathrm{dl}$ and $<7 \mathrm{~g} / \mathrm{dl} \mathrm{Hb}$ represent moderate and severe anemia respectively [13]. The prevalence of ID in Turkey is $48 \%$ in infants, $21 \%$ to $42 \%$ in children and $14.7 \%$ in adult but that of IDA is $3.1 \%$ in children of age 06 - 16 years and $13.5 \%$ pregnant women [14]. In Canadian general population the prevalence of IDA in children is low 3.5\% to $10.5 \%$ while in aboriginal populations is very high $14 \%$ to $50 \%$ [15]. The high prevalence of IDA in these populations is due to high consumption of evaporated milk, cow's milk after six month age; prolong exclusive breastfeeding, burden of Helicobacter pylori infection, low socioeconomic states, and children of Chinese background, low birth weight infant and cow's milk consumption before 1 year age [5]. The iron deficiency anemia affects 02 billion peoples worldwide [16]. The prevalence of IDA is $05 \%$ worldwide but $18 \%$ among adult women and $10 \%$ in adult men in developing countries [17].

\section{Methodology}

\subsection{Study Area}

There are 25 districts in Khyber Pakhtunkhwa but the present study was conducted to investigate anemia in district Karak Khyber Pakhtunkhwa Pakistan. Karak is one of the Southern districts of Khyber Pakhtunkhwa Pakistan. It has 03 Tehsil; Karak, Takht-E-Nasrati and Banda DaudSha. The district Headquarter is located at a distance of $123 \mathrm{Km}$ from Peshawar, $112 \mathrm{Km}$ Kohat and $56 \mathrm{Km}$ from Bannu. There is only one tribe of Pashtuns “KHATTAK” lives in District Karak.

\subsection{Study Design}

The present study was designed to investigate the rate of low iron causing anemia in children in association with socio economic status, age education and dietary intake in district Karak. For obtaining credible and consolidat- 
ed data, the study district was divided into three clusters, Karak, Takht-E-Nasrati and Banda DaudSha. A questionnaire was designed for this purpose. Some other research methods were used like observation, interviews from school going children by visiting of different primary schools (Male and Female) and hospital. The questionnaire included age, sex, social class, education, use of unfortified cow milk, black tea intake, vitamin supplementation drugs and dietary intake like factors. To know the scio economic status of the people, the study population was divided into 03 economic classes, including Lower, Middle and Upper class. There were also some refusals from respondents. But their number was quite insignificant, having no effect on studt sample size.

\subsection{Sample Collection}

Atotal of 420 blood samples were collected and 140 from each cluster. For the collection of blood samples, collection site was cleaned with antiseptic liquid to kill germs. Blood was drawn from anticubital vein by means of sterilized syringes with the help of male expert from school going children and female nurse from female children. The drawn site was usually inside the elbow or back of the hand. The needle was carefully inserted into the individual vein and the blood was collected. About $01-03 \mathrm{ml}$ blood was collected and poured into red tip EDTA (ethylene diamine tetra acetic acid) tube. During the blood collection the designed questionnaire were also filled from the participant.

\subsection{Laboratory Work}

The blood samples were immediately transported to the Khyber Teaching Hospital (KTH) laboratory. The hemoglobin (Hb), hematocrite (Hct), mean corpuscular volume (MCV), mean corpuscular Hemoglobin (MCH), mean corpuscular hemoglobin concentration (MCHC), red blood cell count (RBC), white blood cell count (WBC), and platelet count were determined by automatic hematological analyzer model Symex Ks-21 having two reagent, cell pack and Stromatolyser-wwt $500 \mathrm{ml}$. The WHO classification was used to characterize anemia in school going children (5 - 11 years) $\mathrm{Hb}<11.5 \mathrm{~g}$ per $\mathrm{dL}(115 \mathrm{~g} / \mathrm{L})$. The anemic patients were further divided into Mild anemia (11.0 - $11.9 \mathrm{~g} / \mathrm{dl})$ and $10-10.9 \mathrm{~g} / \mathrm{dl}$, Moderate anemia (10.0 - $10.9 \mathrm{~g} / \mathrm{dl})$ and $7.0-9.9 \mathrm{~g} / \mathrm{dl}$ and severe anemia $<10.0 \mathrm{~g} / \mathrm{dl}$ and $<7.0 \mathrm{~g} / \mathrm{dl}$ respectively [18]. The individual whose $\mathrm{Hb}$ level was less than the standard level, a smear was prepared and observed under microscope. The low MCV and abnormal, small and pale $\mathrm{RBC}$ is microcytic anemia and consider iron deficiency anemia.

\subsection{Data Analysis}

Data collected was subjected to statistical package, SPSS for desired statistical application, including simple mean and standard deviation.

\section{Results}

A total of 420 school age children (5 - 12 years) with both sexes (boys and girls) were interviewed and clinically examined for the presence of anemia at district Karak. After clinical examination blood samples were collected for further analysis.

Table 1 shows Anemia percentage in school age children (SAC) in whole district Karak. The whole district was divided into three large clusters. Tehsil karak, takht-e-Nasrati and Banda Daud Shah. From each cluster 140 (33.33\%) children were involved in the study. From tehsil Karak 80 boys and 60 girls, tehsil takht-e-Nasrati 83 boys and 57 girls, and Banda Daud Shah 90 boys and 45 girls were examined in the present study. children of the study sample were divided into two groups, anemic and non-anemic. In tehsil Karak $26.4 \%$ of school going children were anemic. The prevalence of anemia in school going children of tehsil Takht-E-Nasrati was 32.1\% and 43.6\% in tehsil Banda Daud Shah. The prevalence was high in tehsil Banda Daud Shah, tehsil Takh-E-Nasrati and tehsil Karak respectively. The total anemic children were $34.0 \%$ and non-anemic were $65.9 \%$. The mean $\mathrm{Hb}$ level of anemic children was 10.7.

Table 2 shows Anemia relation with socio economic condition. The whole population was divided into three classes on the basis of monthly income. The people whose monthly income was $<15,000$ (lower class), $=15,000$ - 20,000 (middle class) and $>20,000$ (upper class). The prevalence of anemia was high (55.8\%) in the children of lower class parents. $32.2 \%$ anemic children belong to middle class and $17 \%$ belong to upper class parents. The incidence of anemia was high in lower class family children because their daily dietary intake was not balance. 
Table 1. Anemia percentage in school age children (SAC) (5 - 12 years) in district Karak.

\begin{tabular}{cccc}
\hline Area/Tehsil & Sample Size & Anemic $(\mathrm{Hb}<11.5 \mathrm{~g} / \mathrm{dL}$ or $115 \mathrm{~g} / \mathrm{L})$ & Hb Mean $\pm \mathrm{SD}$ \\
\hline Karak & 140 & $\mathrm{n}(\%)$ & $10.3 \pm 1.3$ \\
Takht-e-Nasrati & 140 & $45(32.4)$ & $10.0 \pm 1.02$ \\
Banda Daud Shah & 140 & $61(43.6)$ & $9.5 \pm 1.67$ \\
Total & 420 & $143(34.0)$ & $10.7 \pm 2.00$ \\
\hline
\end{tabular}

Table 2. Anemia association with socio-economic condition among school age children.

\begin{tabular}{cccc}
\hline Socio-economic condition & Normal Hb level & Anemic $(\mathrm{Hb}<11.5$ g/dL) & Total \\
\hline Lower class $<15,000$ & $\mathrm{n}(\%)$ & $67(55.8)$ & 120 \\
Middle class $=15,000$ up to 20,000 & $53(44.2)$ & $50(32.2)$ & 155 \\
Upper class $>20,000$ & $105(67.7)$ & $26(17.9)$ & 145 \\
Total & $119(82.0)$ & $143(34.0)$ & 420 \\
\hline
\end{tabular}

Table 3 shows Gender wise distribution of anemic children. In tehsil Karak 25\% boys and 28\% girls have low $\mathrm{Hb}$ value than normal and were anemic. $30.1 \%$ boys and $35.0 \%$ girls was anemic in tehsil Takht-e-Nasrati and 36.1\% boys $57.8 \%$ girls in tehsil Banda Daud Shah. The incidence was high in tehsil Banda Shah. The prevalence of anemia was more in girls than boys. The total numbers of anemic girls were $28.3 \%$ in tehsil Karak, $35.0 \%$ in tehsil Takht-e-Nasrati and 57.8\% in tehsil Banda Daud Shah. The total percentage of anemia was 38.9\% in girls and $31.0 \%$ in boys. The percentage was more in girls than boys.

Table 4 shows Age wise distribution of anemic children. According to age, the children were divided into three groups. The percentage of anemia in children at age (10 - 12 years) was high (40\%) than other age groups. The incidence of anemia was $27 \%, 32.1 \%$ and $40 \%$ from age (5 - 8), (8 - 10) and (10 - 12) years respectively. The mean Hb level of anemic children's age (5 - 8 years) was 10.6, children (8 - 10 years) were 10.02 and 10 12 years was 9.5. The data is shown in Table 4 .

Table 5 shows Hemoglobin status of anemic children under age of 5 - 12 years by its severity. The anemia was classified into three groups, Mild, Moderate and Sevier anemia. 46.8\% of children was mild anemic. While the percentage of moderate anemia and severe anemia was $40.5 \%$ and $121.6 \%$ respectively. The distribution data is clearly seen in Table 5 .

\section{Discussion}

The present study was based on 420 school age children ranging from 05 - 12 years included both sexes (Male and Female) of district Karak. Anemia is one of the widespread health problems among children and pregnant women especially in developing countries. The present study estimated iron deficiency anemia in district Karak, in Khyber Pakhtunkhwa Pakistan. The percentage of anemia in children of both sexes (age 05 - 12 years) was $34.0 \%$ in district Karak. The anemia percentage in this age was high because the children require nutritional diet for rapid growth. The prevalence of anemia in children at Africa was 60\%, Latin America (46\%), Eastern Mediterranean (63\%), Southeast Asia I (49\%), southeast Asia II (66\%) and north America 7\% [19]. In Pakistan the survey conducted by National Health survey for Pakistan (NHSP) in 1990-1994 shows that the nutritional anemia in children under age of 05 years was $62.9 \%$. The prevalence of anemia among urban school children of Panjab was 51.5\% [20].

The incidence of anemia was high in girls (38.9\%) as compared to boys (31.0\%) in district Karak, because most of the parents prefer to male children as compared to female children. According to Verma et al. [20] the prevalence of anemia was high in girls $51.1 \%$ among the urban school children of Panjab than boys except 05 years and 10 - 12 years age. In Bangalore district of South India the prevalence of anemia in girls (15.3\%) was also high than boys (12.0\%) The low prevalence in Bangalore was due to school based intervention program that have been conducted 2003 [21]. In Rishikesh, Utterakhand, India the percentage of anemia was 56.5\% in school age children. There was high proportion (36.5\%) in menarcheal girls. $90.90 \%$ anemic children were belonging to lower socio-economic family. The most common anemia was microcytic hypochromic type. It indicates that it is 
Table 3. Gender wise distribution of anemic children.

\begin{tabular}{|c|c|c|c|}
\hline Gender/Tehsil & Normal Hb level & Anemic $(\mathrm{Hb}<11.5 \mathrm{~g} / \mathrm{dL})$ & Total \\
\hline & $\mathrm{n}(\%)$ & $\mathrm{n}(\%)$ & $\mathrm{n}=420$ \\
\hline \multicolumn{4}{|l|}{ Karak } \\
\hline Boys & $60(75)$ & $20(25)$ & 80 \\
\hline Girls & $43(71.7)$ & $17(28.3)$ & 60 \\
\hline \multicolumn{4}{|l|}{ Takht-e-Nasrati } \\
\hline Boys & $58(69.8)$ & $25(30.1)$ & 83 \\
\hline Girls & 37 (64.9) & $20(35.0)$ & 57 \\
\hline \multicolumn{4}{|l|}{ Banda Daud Shah } \\
\hline Boys & $60(63.2)$ & $35(36.8)$ & 95 \\
\hline Girls & $19(42.2)$ & $26(57.8)$ & 45 \\
\hline \multicolumn{4}{|l|}{ Total } \\
\hline Boys & 178 (69) & $80(31.0)$ & 258 \\
\hline Girls & $99(61.1)$ & 63 (38.9) & 162 \\
\hline
\end{tabular}

Table 4. Age wise hemoglobin status of all school age children.

\begin{tabular}{ccccc}
\hline Age in years & Normal Hb level & Anemic $(\mathrm{Hb}<11.5 \mathrm{~g} / \mathrm{dL})$ & Hb Mean \pm SD & Sample Size \\
\hline $5-08$ & $\mathrm{n}(\%)$ & $\mathrm{n}(\%)$ & $10.6 \pm 1.01$ & $\mathrm{n}=420$ \\
$8-10$ & $80(72.7)$ & $30(27.3)$ & $10.02 \pm 1.15$ & 110 \\
$10-12$ & $95(67.8)$ & $45(32.1)$ & $9.5 \pm 1.32$ & 140 \\
Total & $102(60)$ & $68(40.0)$ & $10.7 \pm 2.00$ & 470 \\
\hline
\end{tabular}

Table 5. Clinical signs and symptoms in anemic children.

\begin{tabular}{ccc}
\hline Sign and Symptoms & Anemic $(\mathrm{Hb}<11.5 \mathrm{~g} / \mathrm{dL})$ & Percentage (\%) \\
\hline Pale Skin & $\mathrm{n}$ & 46.9 \\
Weakness & 67 & 32.9 \\
Fatigue & 47 & 16.1 \\
Pale Conjunctiva & 23 & 4.2 \\
Total & 6 & 100 \\
\hline
\end{tabular}

due to lack of nutrient [22].

The percentage of anemia was high in age groups (10 - 12 years) $40 \%$ and in (08 - 10 years) 32.1\% children as compared to age groups (05 - 08 years) $27 \%$ child because at this age the children body requires balance nutrition for rapid growth. In Pakistan the children are admitted in school at the age of 05 years. At that age, there are more burdens on children and need more nutrition. According to age wise distribution; the prevalence of anemia was high (48\%) at age 09 - 12 years in Rishikesh, Uttrakhand, India and 15.5\% in 05 - 08 years child [22]. The present findings were in line with the previous studies. The survey conducted in school age children of Dera Ismail khan (Pakistan) by Ramazan et al, [23] shows that (58.82\%) boys were anemic with maximum at age 06 years and (70\%) girls were anemic with maximum at age 06 years (100\%) and 10 years (66.66\%).

The incidence of anemia was high in lower class (55.8\%) children followed by middle class (32.2\%) and upper class (17\%) children in the present study. Similar findings were reported by Villalpando et al. [24] in Mexican preschool and school age children in 1999-2006. In 1999 the percentage was 28.1\%, 24.7\% and 22.1\% in lower, middle and upper class children respectively thus percentage of anemia was reduced (19.6\%) in lower class, middle class (17.2\%) and in upper class (16.6\%) in 2006 under age 5 - 11 years children. Similar findings were recorded by Jain and Jain, [22] show that anemia was more common (90.90\%) in the children belonging to the lower socio economic level and 37.5\% children of upper and middle class were anemic in Rishikesh, Uttrakhand, India. The prevalence of anemia in undernourished children was high (66.89\%) and in nourished 
group were (29.09) [22]. It is estimated that the incidence of anemia in school age children in age groups (05 12 years) was high (46\%) in developing countries especially highest rates found in Africa (49\%) and in South Asia (50\%). The anemia prevalence among school age children was 35\% in mountainous region from Northern Morocco [25].

The percentage of Mild anemia (Hb 10 to $<11 \mathrm{~g} / \mathrm{dL}$ ) (46.8\%) in children was high followed by moderate (Hb 7 to $<10 \mathrm{~g} / \mathrm{dL}$ ) (45.5\%) and severe anemia ( $\mathrm{Hb}<7 \mathrm{~g} / \mathrm{dL})(12.6 \%)$. The percentage of mild anemic (11.2\%), moderate anemic (2.1\%) and severe anemic were $(0.3 \%)$ in school age children of Bangalore which was similar to the present study [21]. Mild anemia $>$ Moderate anemia $>$ Sever anemia.

\section{Conclusion}

It is concluded from the present study that the problem of anemia was high in school age children. The percentage of anemia among school age children was high (34.0\%) in district Karak. In different tehsil, the incidence was high (43.6\%) in Banda Daud Shah. This is urban region of the district Karak. It means that the anemia was more prevalent in rural region than in urban area. While in other regions of the district it was $32.1 \%$ in Takht-eNasrati and 26.4\% in tehsil Karak. In children the presence of anemia reduces immunity, physiological development and reduces physical and mental activities. The percentage of anemia was higher in girls (38.9\%) than boys (31.0\%) and more in lower class (55.8\%) family children. According to age-wise, 10 - 12 years children were more anemic. Most of the children were mild anemic. The symptoms of anemia were difficult to detect and diagnose but the Pale skin was the most common symptom of anemia.

\section{Acknowledgements}

We would like to extend our sincere gratitude to Professor Dr. Shah Jehan, Department of Zoology, Peshawar University, Peshawar, for the critical reading of the manuscript.

\section{References}

[1] Idris, M. and Rehman, A.U. (2005) Iron Deficiency Anaemia in Moderate to Severely Anaemic Patients. Journal of Ayub Medical College, Abbottabad: JAMC, 17, 45-47.

[2] Ullah, I., Zahid, M., Khan, M.I. and Shah, M. (2013) Prevalence of Anemia in Pregnant Women in District Karak Khyberpakhtunkhwa, Pakistan. International Journal of Biosciences, 3, 77-83. http://dx.doi.org/10.12692/ijb/3.11.77-83

[3] Bakhtiar, U., Khan, Y. and Nasar, R. (2007) Relationship between Maternal Related Hemoglobin and Perintal Outcome. Rawal Medical Journal, 32, 102-104.

[4] Molla, A., Khaurshed, M. and Molla, A.M. (1992) Prevalence of Iron Deficiency Anaemia in Children of the Urban Slums of Karachi. Journal of Pakistan Medical Association, 42, 118-121.

[5] Thaver, I.H. and Baig, L. (1994) Anaemia in Children, Can Simple Observation by Primary Care Provider Help in Diagnosis? Journal of Pakistan Medical Association, 44, 282-284.

[6] Christofides, A., Schauer, C. and Zlotkin, S.H. (2005) Iron Deficiency Anemia in among Children: Addressing a Global Public Health Problem within a Canadian Context. Paediatrics and Child Health, 10, 597-601.

[7] Looker, A.C., Dallman, P.R., Carrol, M.D., Gunter, E.W. and Johnson, C.L. (1997) Prevalence of Iron Deficiency in the United States. The Journal of the American Medical Association, 277, 973-976.

http://dx.doi.org/10.1001/jama.1997.03540360041028

[8] Weissinger, F. (1999) Basic Principals and Clinical Significance of Iron-Deficiency. Fortschritte der Medizin, 115, 3538.

[9] Sakiewiez, P. and Pagarini, E. (1998) The Use of Iron in Patients on Chronic Dialysis: Mistake and Misconceptions. Journal of Nephrology, 11, 5-15.

[10] Irwin, J.J. and Kirchner, J.T. (2001) Anemia in Children. American Family Physician, 64, 1379-1386.

[11] Villapando, S., Shamah-Levy, T., Ramirez-Silva, C.V., Mejia-Rodriguez, F. and Rivera, J.A. (2003) Prevalence of Anemia in Children 1 to 12 Years of Age. Results from a Nationwide Probabilistic Survey in Mexico. Salud Pública de México, 45, S490-S498. http://dx.doi.org/10.1590/S0036-36342003001000005

[12] Ramakrishnan, U. (2002) Prevalence of Micronutrient Malnutrition Worldwide. Nutrition Reviews, 60, S46-S52. http://dx.doi.org/10.1301/00296640260130731 
[13] Akhtar, S., Ahmed, A., Ahmad, A., Ali, Z., Riaz, M. and Ismail, T. (2013) Iron Status of the Pakistani PopulationCurrent Issues and Strategies. Asia Pacific Journal of Clinical Nutrition, 22, 340-347.

[14] Karaoglu, L., Pehlivan, E., Egri, M., Deprem, C., Gunes, G., Genc, M.F. and Temel, I. (2010) The Prevalence of Nutrition Anemia in Pregnancy in an East Anatolian Province, Turkey. BMC Public Health, 10, 329. http://dx.doi.org/10.1186/1471-2458-10-329

[15] Harfield, D. (2010) Iron Deficiency Is a Public Health Problem in Canadian Infant and Children. Paediatrics and Child Health, 15, 347-350.

[16] Yates, J.M., Logan, E.C. and Stewart, R.M. (2004) Iron Deficiency Anemia in General Practice: Clinical Outcomes over Three Years and Factors Influencing Diagnostic Investigations. Postgraduate Medical Journal, 80, 405-410. http://dx.doi.org/10.1136/pgmj.2003.015677

[17] Vahidinia, A. and Shams, S. (2004) Irondeficiency amongst Nursing Students. Indian Journal of Medical Sciences, 58, 389-393.

[18] Paracha, P.I., Hameed, A., Simon, J., Jamil, A. and Nawab, G. (1997) Prevalence of Anemia in Simi-Urban Areas of Peshawar Pakistan: A Challenge for Health Professionals and Policy Makers. Journal of Pakistan Medical Association, 47, 49-53.

[19] Stoltzfus, R.J. (2003) Iron Deficiency: Global Prevalence and Consequences. Food and Nutrition Bulletin, 24, S99S103.

[20] Verma, M., Chhatwal, J. and Kaur, G. (1998) Prevalence of Anemia among Urban School Children of Panjab. Indian Pediatrics, 35, 1181-1185.

[21] Muthayya, S., Thankachan, P., Zimmermann, M.B., Andersson, M., Eilander, A., Miquith, D., Hurrell, R.F. and Kurpad, A.V. (2007) Low Anemia Prevalence in School-Aged Children in Bangalore, South India: Possible Effect of School Health Initiatives. European Journal of Clinical Nutrition, 61, 865-869.

[22] Jain, N. and Jain, V.M. (2012) Prevalence of Anemia in School Children. Academic Journals, 3, 1-4.

[23] Ramzan, M., Ali, I. and Salam, A. (2009) Iron Deficiency Anemia in School Children of Dera Ismail Khan, Pakistan. Pakistan Journal of Nutrition, 8, 259-263. http://dx.doi.org/10.3923/pjn.2009.259.263

[24] Villapando, S., Dhamah-Levy, T., Garcia-Guerra, A., Mundo-Rosas, V., Dominguez, C. and Mejia-Rodriguez, F. (2009) The Prevalence of Anemia Decreased in Mexican Preschool and School-Age Children from 1999 to 2006. Salud Pública de México, 51, S507-S514.

[25] Zimmermann, M.B., Zeder, C., Chaouki, N., Saad, A., Torresani, T. and Hurrell, R.F. (2003) Dual Fortification of Salt with Iodine and Microencapsulated Iron: A Randomized, Double Blind, Controlled Trial in Moroccan School Children. The American Journal of Clinical Nutrition, 77, 425-432. 
Scientific Research Publishing (SCIRP) is one of the largest Open Access journal publishers. It is currently publishing more than 200 open access, online, peer-reviewed journals covering a wide range of academic disciplines. SCIRP serves the worldwide academic communities and contributes to the progress and application of science with its publication.

Other selected journals from SCIRP are listed as below. Submit your manuscript to us via either submit@scirp.org or Online Submission Portal.
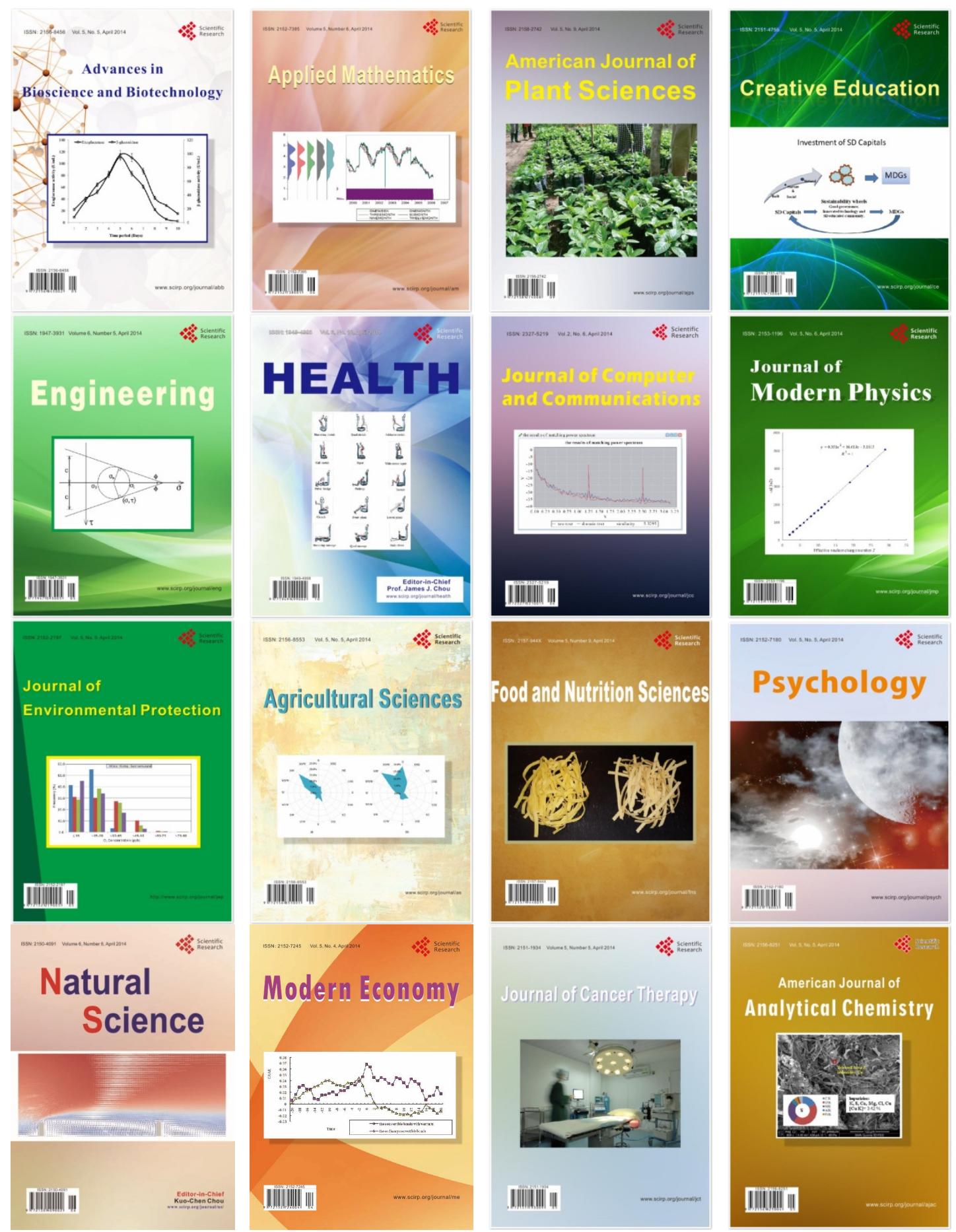